\title{
Betapa Indahnya Kedatangan Mereka Yang Membawa Berita Damai (Yesaya 52:1-12)
}

\author{
Dyulius Thomas Bilo \\ Sekolah Tinggi Teologi Injili Arastamar (SETIA) Jakarta \\ dyuliusthbilo@gmail.com
}

\begin{abstract}
It is interesting to study the phrase "how beautiful it is to come with them who bring messages of peace" in the context of the book of Isaiah. This sentence is appropriate to state how God is the savior and liberator for the Israelites who have been punished through exile and slavery to other nations. But in reality not everyone is able to understand the meaning of this expression. In its exploration, this paper aims to explain how the news of Israel's liberation from exile and slavery, how the state of the Israelites in exile and slavery, how God freed them, how beautiful the deliverance or salvation that God did for the Israelites, and how the correlation of Isaiah's message with Micah's message, Nahum, and the Apostle Paul, and how to interpret the expression "how beautiful the arrival of those who bring messages of peace" in the world of Christian education. It was preceded by an introduction covering the division of Isaiah, the meaning of Isaiah's name, and the ministry of the prophet Isaiah.
\end{abstract}

Keywords: Israel, condemnation, peacemaker, Isaiah

\begin{abstract}
Abstrak: Sangat menarik untuk mengkaji ungkapan "betapa indahnya kedatangan mereka yang membawa berita damai" dalam konteks kitab Yesaya. Kalimat ini tepat untuk menyatakan bagaimana Allah sebagai penyelamat dan pembebas bagi bangsa Israel yang telah dihukum melalui pembuangan dan perbudakan bangsa lain. Namun kenyataannya belum semua orang mampu memahami maksud dari ungkapan tersebut. Dalam eksplorasinya tulisan ini bertujuan menjelaskan bagaimana berita pembebasan Bangsa Israel dari pembuangan dan perbudakan, bagaimana keadaan Bangsa Israel di tempat pembuangan dan perbudakan, bagaimana Allah membebaskannya, bagaimana keindahan pembebasan atau penyelamatan yang Allah kerjakan bagi Bangsa Israel, dan bagaimana korelasi berita Yesaya dengan berita Mikha, Nahum, dan Rasul Paulus, dan bagaimana memaknai ungkapan "betapa indahnya kedatangan mereka yang membawa berita damai" dalam dunia pendidikan Kristen. Sebelumnya didahului pengantar yang mencakup pembagian kitab Yesaya, arti nama Yesaya, dan pelayanan Nabi Yesaya.
\end{abstract}

Kata Kunci: Bangsa Israel, penghukuman, pembawa damai, Yesaya

\begin{abstract}
Pendahuluan
Dalam bagian ini akan dibahas sebelumnya tentang pembagian kitab Yesaya, pengertian nama Yesaya, dan pelayanan Nabi Yesaya. F.L. Baker membagi kitab Yesaya dalam tiga bagian besar, bagian pertama membicarakan zaman Asyur pasal 1-39, bagian kedua mulai pasal 40-54, memuat perkataan-perkataan penghiburan untuk umat Allah, yang mengeluh di Babel dalam pembuangan, dan bagian ketiga, mulai pasal 55-66 memuat umat Yahudi mengharapkan bahwa dengan pembebasan dari Babel (438 sM) dimana Yerusalem akan diliputi damai sejahtera di hadapan Allah. ${ }^{1}$ Sumber lain menyatakan Kitab Yesaya dibagi dalam 3 (tiga) buku utama, yaitu:
\end{abstract}


a. Buku pertama Nabi Yesaya (Proto-Yesaya) pasal 1-39 tentang sejarah Israel dengan muatan celaan-celaan nabi atas dosa-dosa yang menolak Tuhan dengan menyembah ilah lain, serta cacian pedas terhadap para pemimpin yang mengandalkan kekuatan asing dan tidak percaya kepada Allah sebagai satu-satunya yang mampu menyelamatkan mereka.

b. Buku kedua Nabi Yesaya (Deutero-Yesaya) pasal 40-55 masa pembuangan di Babel dengan muatan janji-janji Allah bahwa mereka akan kembali dari pembuangan, tetapi juga kecaman keras bagi yang percaya kepada berhala dan tidak percaya kepada Allah Israel yang hidup.

c. Buku ketiga Nabi Yesaya (Trito-Yesaya) pasal 56-66 sesudah kembalinya dari pembuangan fokus kepada pembangunan kembali Bait Allah di Gunung Sion. Tetapi Allah lebih berkenan kepada keadilan dan kesetiaan daripada ibadat dan pembangunan Bait Allah. ${ }^{2}$

Namun jika kita perhatikan masing-masing Alkitab kita, Kanonika Yesaya khususnya dalam terjemahan New King James Version (NKJV), kita akan mendapatkan pembagiannya sebagai berikut:

1. Pasal 1 - 39 Bagian Pertama, yang lebih detail terdiri dari:

a. Pasal 1-12 Nubuat tentang Yehuda dan Yerusalem

b. Pasal 13-23 Nukuman terhadap bangsa-bangsa

c. Pasal 24-27 Nubuat tentang akhir zaman

d. Pasal 28-35 Yerusalem tersesak dan terlepas

e. Pasal 36-39 Yesaya dalam zaman Hizkia

2. Pasal 40 -66 Bagian Kedua, yang lebih detail terdiri dari:

a. Pasal 40-48 Keselamatan untuk bangsa yang di dalam pembuangan

b. Pasal 49-55 Hamba Tuhan

c. Pasal 56-66 Penggenapan keselamatan dan syarat-syaratnya

Yesaya dalam bahasa Ibarani yesya'yahu artinya Yahweh adalah keselamatan. Ia adalah putra dari Amos (tetapi bukan nabi Amos. Ia tinggal di Yerusalem (Yes. 7:1-3; 37:2). Sesuai tradisi ia berasal dari keluarga raja dan keturunan bangsawan. Ia memiliki istri yang disebutnya dalam 8:3. Dua anaknya disebutkan dengan nama simbolis atau disebut "tanda dan alamat" (8:18), Shear Yasyub, artinya "sisa itu akan kembali" (7:3) dan Maher-Syalal Hasy-Bas, artinya "percepatlah merampas, bersegerahlah merampok (8:1-4). ${ }^{3}$

Yesaya hidup sezaman dengan Mikha (1:1 dengan Mikha 1:1). Namun aktifitasnya didahului oleh Nabi Amos dan Hoses (Am. 1:1; Hos. 1:1). Amos dan Hosea bernubuat untuk suku-suku di Israel Utara dan Yesaya dan Mikha bernubuat di Yehuda atau Yerusalem (Yes. 1:1). Pada zaman Uzia (791/790-74-/739 sM), Yotam (740/739-732-/731 sM), Ahas (735716/715sM), dan Hizkia (716/715-687/686 sM).

Pada paruh waktu abad 8, baik di Israel Utara pada pemerintahan Yerobeam II (kira2 782-753 sM), maupun di Yehuda pada pemerintahan Uzia, menikmati masa makmur raya. Ini dikarenakan sebagian besar lemahnya kerajaan Aram dan alpanya campur tangan Asyur di wilayah Barat. Pemerintahan Uzia boleh dikatakan sebagai masa paling makmur yang dikenal Yehuda sampai zaman Yotam keadaan berkelimpahan dan makmur digambarkan Yesaya 2-4. Tetapi naiknya Tiglat-Pileser III (745-727 sM) di tahta kerajaan, memacu Asyur kembali mengembangkan sayapnya ke Barat. Pekah dari Israel Utara dan

2Dapat dilihat dalam http://psbrahmana.blogspot.com/2012/12/khotbah-yesaya-527-10-senin-24desember.html (diakses 20 Juli 2018, pukul 22:00 WIB)

${ }^{3}$ E.J.Kissane "The Book of Isaiah I " dalam J.D. Dauglas (penyunting), Ensiklopedi Alkitab Masa Kini Jilid II M-Z (Jakarta: YKBK/OFM, 2007),576. 
Rezin dari Aram membentuk koalisi anti Asyur. Mereka berusaha memaksa Ahas dari Yehuda bergabung dengan mereka. Karena Ahas menolak, maka mereka mengancam akan menyingkirkannya dan menempatkan raja boneka menduduki tahta Ahas (734 sM). Tindakan Yesaya pada waktu itu diberitakan dalam pasal 7. Namun suatu kebodohan dibuat raja Ahas dengan meminta bantuan raja Asyur, akibatnya Yehuda menjadi negara satelit Asyur. Bakker menjelaskan bahwa dalam peperangan antara Aram-Efraim melawan Ahas, yang mencari bantuan dari pada Asyur, maka Yesaya datang kepada Ahas untuk menasihati raja, supaya percaya kepada Tuhan. Dicelanya dosa Israel dengan mengemukakan berulang-ulang kerajaan damai di bawah pemerintahan Mesias yang akan datang. ${ }^{4}$

Sesudah peristiwa itu, beberapa kali gerakan kemerdekaan dilancarkan untuk menentang kekuasaan Asyur, Yesaya menyampaikan nubuat protes menetang politik luar negeri Ahas pada tahun $734 \mathrm{SM}$, namun tidak digubris juga (8:16), juga Yehuda terlibat politik luar negeri dengan bekerja sama dan meminta bantuan Mesir, namun Yesaya bangkit menolak gerakan politik ini (14:29-32). Pada zaman Hizkia juga timbul gerakangerakan politik di Asdod (20:1). Yehuda dengan sekutunya terlibat pemberontakan ini. Pemberontakan ini memancing Sanherib (705-681 sM) menyerbu Yehuda dan mengepung Yerusalem. Berbagai ucapan ilahi disampaikan (28-31), Nabi Yesaya menyampaikan nubuatnya (38-39).

\section{Metode Penelitian}

Pada penelitian ini, penulis atau peneliti menggunakan pendekatan atau metode kualitatif untuk memperoleh data yang valid guna membangun sebuah teori yang berkaitan dengan tema atau pokok penelitian. Metode kualitatif yang dimaksud adalah mengkaji dan mengelaborasi setiap sumber, informasi dan data-data yang diperoleh dari pustaka.

\section{Hasil dan Pembahasan}

Eksplorasi bagian ini terdiri dari: Pertama, Exordium (pendahuluan) "Pembebasan Bangsa Israel dari Pembuangan dan Perbudakan", kedua, Narratio (menceritakan) "Keadaan Bangsa Israel di tempat pembuangan dan perbudakan", ketiga, Probatio (argumentasi)"Allah yang Membebaskan Bangsa Israel", keempat, Confutatio (pembuktian) "Keindahan Pembebasan Allah bagi Bangsa Israel”

\section{Exordium (pendahuluan) "Pembebasan Bangsa Israel dari Pembuangan dan Perbudakan"}

Judul yang diangkat di atas diambil dari buku kedua Nabi Yesaya (pasal 40-55) dimana pada waktu itu orang Israel khususnya Israel Selatan (suku Yehuda) berada di pembuangan di Babel. Yang secara spesifik bicara tentang hamba Tuhan (menurut NKJV). Dalam Yesaya 52 -53 disebut sebagai hamba Tuhan yang menderita.

Dalam ayat 1 dan 2 yang disebut sebagai kalimat pembukaan, karena Yerusalem dibebaskan Allah dari hukuman, maka ia dapat berjaga, ia dapat bangun (51:17), ia dapat mengebaskan debu yang mengotorinya dan selagi harus tunduk karena pekerjaan kerja rodi (51:23), ia dapat menanggalkan ikatan leher, karena ia tidak lagi seorang budak tawanan perang yang diikatkan lehernya kepada leher orang lain dengan tali yang tebal (seperti gambaran ukiran di Babel). Orang yang diberi kemerdekaan oleh Tuhan dapat mengenakan pakaian orang kuat, orang terhormat (dalam bahasa Ibrani "oz" berarti kehormatan, kemuliaan, perhiasan yang memperlihatkan bahwa seseorang berdiri dalam jabatan bangsawan atau imam), harus kelihatan bahwa Yerusalem tidak merupakan budak lagi. 
Di dalam pakaian kehormatan, Sion memperlihatkan dirinya sebagai kota yang kudus, kota pilihan TUHAN yang disucikan bagi-Nya. Sebagai akibat dari pada itu orangorang tak bersunat, orang-orang Babel (49:17), tetapi juga untuk musuh-musuh yang lain, seperti orang Asyur, Mesir dan Filistin yang juga tak bersunat, tidak akan masuk lagi untuk merusakannya, demikianlah orang-orang najis, mereka yang tidak menyucikan diri bagi TUHAN (ay.11), mereka yang tidak mau mengerti kehendak-Nya (orang-orang tidak tahir, orang-orang pandir (35:8), orang-orang berdosa dan orang-orang najis bibir (6:4), tidak dapat memasuki kota di mana TUHAN tinggal (ay.8) dan sebagai Raja (ay.7). ${ }^{5}$

Ayat 1 dan 2 mengingatkan Israel sebagai umat atau bangsa pilihan Tuhan yang adalah sesungguhnya kaum terhormat, bermartabat, mulia, teragung, dan kaum bangsawan karena dicipta Tuhan menurut gambar-Nya (Kej. 2:27) dan ditetapkan menjadi umat pilihan Tuhan di tengah- tengah umat atau bangsa lain (Kej. 12), pribadi dan kelompok yang diberkati Tuhan (Kej.27:33), pribadi dan kelompok yang bergumul dengan Tuhan dan menang (Kej. 32:24-25), pribadi dan kelompok yang dibela oleh Tuhan dan nama Allah Israel adalah Allah (Kej.33:20). Mereka bukanlah pribadi dan kelompok tawanan yang begitu rendah martabatnya, mereka bukanlah pekerja rodi tanpa upah, mereka sepatutnya mengenakan pakaian kehormatan raja. Tetapi mengapa demikian tragisnya hidup mereka, begitu menyedihkan kehidupan mereka. Jawabannya adalah karena dosa membuat mereka memberontak dan melawan Allah, sehingga penghukuman Tuhan berlaku atasnya melalui pembuangan ke bangsa lain.

\section{Narratio (menceritakan) "Keadaan Bangsa Israel di tempat pembuangan dan perbudakan"}

Dalam ayat 3-5 memperlihatkan Yerusalem sebagai budak tawanan yang dibebaskan TUHAN adalah berdekatan dengan gambaran bahwa Israel terjual menjadi malu (Mzm. 44:6), bekerja tanpa bayaran dan tanpa untung (Yes.52:3), dan orang terhutang (50:1). Itulah sebabnya orang Israel ditebus juga tanpa bayaran oleh Tuhan $(45: 13 ; 52: 3)$. Bayangan ini mungkin berasal dari Yesaya II dikaitkan keadaan hidup orang Israel di Mesir dan sewaktu pemerintahan di Asyur memeras mereka. Israel yang semestinya diperlakukan menurut hak yang lazim bagi penumpang asing yang datang menetap atas kemauan sendiri di suatu kota atau negeri dijadikan budak tanpa alasan. Pada masa itu dan juga saya mengira berlaku pada masa sekarang ini, ketika seseorang pergi merantau ke suatu tempat atau kota lain untuk mencari pekerjaan yang layak. Tentu mereka akan bekerja sesuai dengan kesepakatan dan berhak mendapat upah yang pantas dan layak.

Tetapi berbeda dengan kehidupan umat Israel pada waktu itu baik di Mesir maupun di Babel mereka tidak diperlakukan sebagai pekerja yang patut mendapat upah, melainkan sebagai pekerja rodi tanpa upah sekalipun. Kita bisa bayangkan rintihan piluh orang Israel di Mesir dalam Keluaran 1:8, 11-14 "Kemudian bangkitlah seorang raja baru memerintah tanah Mesir, yang tidak mengenal Yusuf.... Sebab itu pengawas-pengawas rodi ditempatkan atas mereka untuk menindas mereka dengan kerja paksa: mereka harus mendirikan bagi Firaun kota-kota perbekalan, yakni Pitom dan Raamses. Lalu dengan kejam orang Mesir memaksa orang Israel bekerja, dan memahitkan hidup mereka dengan pekerjaan yang berat, yaitu mengerjakan tanah liat dan batu bata, dan berbagai-bagai pekerjaan di padang, ya segala pekerjaan yang dengan kejam dipaksakan orang Mesir kepada mereka itu." dan Keluaran 5:6-8 "Pada hari itu juga Firaun memerintahkan kepada pengerah-pengerah bangsa itu dan kepada mandur-mandur mereka sendiri: "Tidak boleh lagi kamu memberikan jerami kepada bangsa itu untuk membuat batu bata, seperti sampai sekarang; biarlah mereka sendiri yang pergi mengumpulkan jerami, tetapi jumlah batu bata, yang

${ }^{5}$ Marie-Claire Barth, Tafsiran Alkitab: Kitab Yesaya Pasal 40-55 (Jakarta: BPK. Gunung Mulia, 1996), 
harus dibuat mereka sampai sekarang, bebankanlah itu juga kepada mereka dan jangan menguranginya, karena mereka pemalas. Itulah sebabnya mereka berteriak-teriak: Izinkanlah kami pergi mempersembahkan korban kepada Allah kami. Pekerjaan orangorang ini harus diperberat, sehingga mereka terikat kepada pekerjaannya."

Sebenarnya Asyur juga tidak mempunyai alasan untuk memeras atau menindas Israel (terlepas dari kesaksian para nabi, namun Asyur dipakai Tuhan untuk menjalankan hukuman yang telah diputuskan TUHAN bagi orang Israel (Yes.10:6-11). ${ }^{6}$ Tetapi karena Asyur tidak taat juga kepada Allah, maka Asyur dihukum juga oleh Tuhan.

Keadaan hidup orang-orang Israel di pembuangan Babel secara sosial, psikologi, moral dan rohani sangat memilukan hati Tuhan. Para pengerah dan mandor (dari orang Babel) merasa congkak dan pongah dan berkata bahwa Allah yang disembah orang Israel tidak sanggup menolong mereka. Dewa Babel lebih kuat dan hebat dibanding Allah Israel. Raja dan tentara Babel sangat hebat tidak mungkin terkalahkan oleh siapa pun, dan bangsa yang hebat seperti Israel dan Allahnya yang hebat itu tidak bisa berbuat apa-apa.

Mereka lupa bahwa orang Israel yang ditawan dan berada dipembuangan karena ketidaktaatan dan ketidaksetiaan bangsa Israel kepada Tuhan. Maka Tuhan menghukum mereka dan mengijinkan bangsa Asyur, Bebal, dan Mesir menjajah dan menawan mereka. Tetapi sebaliknya dalam kondisi seperti itu, tidak ada dari orang Israel yang beriman dan percaya kepada Tuhan bahwa suatu saat akan ada pembebasan dari Tuhan. Hendaknya ketika mereka ditindas dan dijajah bangsa Babel, orang Israel mencari Allah, meminta tolong kepada Allah, meminta petunjuk kepada Allah. Malah sebaliknya karena penindasan itu, orang Israel makin jauh dari Tuhan, mereka tidak lagi ingat dan percaya Tuhan.

Karena kondisi tersebut, dalam ayat 5 Yesaya menuliskan "Tetapi sekarang, apakah lagi urusan-Ku di sini? demikianlah firman TUHAN. Umat-Ku sudah dirampas begitu saja. Mereka yang berkuasa atas dia memegahkan diri, demikianlah firman TUHAN, dan nama-Ku terus dihujat sepanjang hari." Dalam terjemahan lain FAYH "Sekarang, mengapa umat-Ku diperbudak lagi, dan ditindas dengan kejam?" kata TUHAN. "Mereka yang berkuasa atas umat-Ku bersorak-sorak, dan nama-Ku dihujat terus-menerus setiap hari."

Yesaya menuliskan bahwa umat TUHAN dirampas, sehingga TUHAN bertanya secara harfiah "sekarang ada apa bagi-Ku di sini?" yang mau dikontraskan dan dimegah-megahkan adalah nama orang-orang yang berkuasa, yang dinista, terus menerus ialah nama TUHAN (1:4; Mzm.74:10,18), menista firman-Nya (Bil.14:11, Yes.5:24, Yer.23:17, menganggap hina kehendak Allah, dan atau bertindak bertentangan dengan kehendak Allah. ${ }^{7}$ Dan itu dilakukan oleh orang Babel kepada para orang buangan sepanjang hari.

Dari bagian ini kita sangat mengerti bahwa ketika terlalu berat perlakuan para penindas yang dirasakan oleh orang-orang buangan itu, maka sebenarnya apa yang dirasakan itu, dirasakan juga oleh Allah. Dalam Keluaran 3:7-9 dituliskan "Dan TUHAN berfirman: "Aku telah memperhatikan dengan sungguh kesengsaraan umat-Ku di tanah Mesir, dan Aku telah mendengar seruan mereka yang disebabkan oleh pengerah-pengerah mereka, ya, Aku mengetahui penderitaan mereka. Sebab itu Aku telah turun untuk melepaskan mereka dari tangan orang Mesir dan menuntun mereka keluar dari negeri itu ke suatu negeri yang baik dan luas, suatu negeri yang berlimpah-limpah susu dan madunya, ke tempat orang Kanaan, orang Het, orang Amori, orang Feris, orang Hewi dan orang Yebus. Sekarang seruan orang Israel telah sampai kepada-Ku; juga telah Kulihat, betapa kerasnya orang Mesir menindas mereka."

\section{Probatio (argumentasi)"Allah Membebaskan Bangsa Israel"}

${ }^{6}$ Barth, Tafsiran Alkitab: Kitab Yesaya Pasal 40-55,298

7Barth, Tafsiran Alkitab: Kitab Yesaya Pasal 40-55, 298 
Pada ayat 6 dikatakan "Sebab itu umat-Ku akan mengenal nama-Ku dan pada waktu itu mereka akan mengerti bahwa Akulah Dia yang berbicara, ya Aku!" dalam terjemahan BIS "Sebab itu kamu akan mengakui bahwa Aku Allah, dan pada waktu itu kamu akan tahu bahwa Akulah yang berbicara kepadamu." Allah memperkenalkan diri bukan saja turut merasakan apa yang mereka alami, tetapi sesungguhnya mengingatkan orang Israel di pembuangan bahwa ketika mereka dalam penindasan tak berdaya, tidak bisa buat apa-apa termasuk untuk beriman dan percaya kepada Allah pun tidak bisa, Allah berinisiatif memulihkan segala sesuatu dan menyatakan kedahsyatan kekuasaannya. Bahwa bukanlah raja Babel, pengerah, penindas, para mandor yang hebat. Allah mau berkata bahwa mereka tidak ada apa-apanya kalau tidak diizinkan Tuhan. Sesungguhnya yang hebat dan berkuasa atas hidup dan keadaan Israel di pembuangan adalah Allah yang sedang berbicara itu. Allah yang nama-Nya pernah dan terus dikenal sesungguhnya oleh orang Israel. Dalam Keluaran 3;13-15 "Lalu Musa berkata kepada Allah: "Tetapi apabila aku mendapatkan orang Israel dan berkata kepada mereka: Allah nenek moyangmu telah mengutus aku kepadamu, dan mereka bertanya kepadaku: bagaimana tentang nama-Nya? -- apakah yang harus kujawab kepada mereka?" Firman Allah kepada Musa: "AKU ADALAH AKU." Lagi firman-Nya: "Beginilah kaukatakan kepada orang Israel itu: AKULAH AKU telah mengutus aku kepadamu." Selanjutnya berfirmanlah Allah kepada Musa: "Beginilah kaukatakan kepada orang Israel: TUHAN, Allah nenek moyangmu, Allah Abraham, Allah Ishak dan Allah Yakub, telah mengutus aku kepadamu: itulah nama-Ku untuk selama-lamanya dan itulah sebutan-Ku turun-temurun."

Nama itu yaitu nama TUHAN yang sanggup membebaskan mereka dari tangantangan buas sang penindas, pengerah, dan mandor di pembuangan, nama TUHAN itu jugalah yang akan memerdekakan mereka dan akan membawa mereka kembali ke kampung halaman mereka, ke kota kediaman mereka di Yerusalem, di kota Sion.

Pada saat itulah (ay 6) orang Israel yang sudah mengenal kembali Allah mereka, mereka akan mengerti nama TUHAN dan mengakui nama TUHAN (kepribadian, kehendak, dan perbuatannya), seperti kalimat Akulah Dia yang berbicara, ya Aku. Barth berkata, rumus memperkenalkan diri ini semestinya membuka mata akan suatu janji ilahi dan kiranya diartikan di sini: Inilah Aku yang menebus kamu. Penyelamat Israel sepanjang sejarah dan penggenapannya pada hari kiamat menjadi hiburan bagi umat yang masih tertindas di pembuangan. ${ }^{8}$

Berpijak dari hal itu (ay.7-10) TUHAN membuka hal baru bagi mereka untuk suatu tempat yang patut dan layak bagi mereka; bukan di tempat pembuangan (Asyur, Babel, dan Mesir), melainkan ditempatnya semula; suatu tempat yang dulu pernah dijanjikan bagi orang Israel waktu mereka di Mesir, suatu tempat yang menjadi impian nabi Musa, suatu tempat yang rebut Yosua dan Kaleb, dan suatu tempat atau negeri warisan turun temuran orang Israel, suatu tempat yang orang-orang Israel dan nenek moyangnya diberkati dan hidup dalam kelimpahan, suatu tempat atau negeri yang sekarang kesepian karena mereka tinggalkan ke pembuangan, yaitu tanah Kanaan, kota Sion, Kota Yerusalem. Dari ayat 7-10, Nabi Yesaya sebelumnya melukiskan keadaan mereka di kota pembuangan, Babel, kini Yesaya beralih melukiskan kota Yerusalem itu sendiri. Kota Yerusalem-Sion adalah kota berbukit-bukit kota bergunung-gunung.

\section{Confutatio (pembuktian) "Keindahan Pembebasan Allah bagi Bangsa Israel”}

Dalam ayat ini "menjadi titik sentral judul tulisan ini" ada tiga hal yang menyangkut dengan keindahan di sini yaitu: Bukit-bukit atau gunung-gunung yang indah, siapa yang muncul dibalik bukit-bukit atau gunung-gunung itu memberitakan kabar damai dan kabar baik, dan berita yang disampaikan. 
Pertama keindahan Bukit-bukit atau gunung-gunung Yerusalem. Saya belum pernah ke Israel, tetapi menurut informasi dari sisi geografis, keadaan Yerusalem dulu dengan sekarang tidaklah terlalu berbeda. Kota Yerusalem yang letaknya lebih rendah atau berada di lembah di kelilingi bukit-bukit dan gunung-gunung yang indah (seperti bukit Zaitun, bukit Betania, bukit atau gunung Golguta). Di dalam kota Yerusalem yang di tengah-tengah gunung-gunung/bukit-bukit (Mzm. 125:2), dengan kata ini nabi memperkenalkan Yerusalem) yang dinanti-nantikan beritanya (2 Sam.18:19-28; Yes.21:6-9). Adanya bukitbukit atau gunung-gunung ini mengindikasikan daerah Yerusalem adalah daerah perbukitan atau pegunungan yang sejuk dengan tumbuh-tumbuhan yang hijau dan menawan hati. Dengan anugerah khusus dari Allah (berupa pengetahuan alam dan keterampilan pertanian (bercocok tanam) dan beternak), orang Israel hingga kini meneguhkan diri sebagai bangsa yang mampu dan berhasil mengelolah daerah pegunungan atau perbukitan menjadi lahan-lahan pertanian yang subur untuk mensuplai kebutuhan sayur mayur dan buah-buahan bagi Israel dan negara-negara tetangganya.

Keindahan yang kedua, pembawa berita damai atau kabar baik atau berita syalom. Yesaya coba ingatkan orang-orang buangan di Babel adalah siapa yang akan muncul dibalik perbukitan atau pegunungan tersebut. Nabi Yesaya menggambarkan keadaan ini, pada saat si pembawa berita kelihatan di atas gunung pada kaki langit dapat diduga dari caranya berlari bahwa yang dibawanya ialah berita damai (Ibrani "syalom" Yes. 54:10,13); si pembawa berita turun ke lembah dan tidak nampak lagi, lalu muncul kembali di bukit yang lebih dekat dan dari tanda yang diberikannya sudah pasti bahwa kabar yang akan disampaikannya adalah baik isinya; sekali lagi ia tersembunyi dan kelihatan lagi begitu dekat, sehingga dari seri mukanya kentara bahwa ia membawa berita keselamatan (ay.10; $43: 12 ; 49: 25) .^{9}$

Dalam sejarah Israel dan ini untuk mengingatkan orang-orang Israel pada hal-hal biasa terjadi di masa lampau; Tatkala ada peperangan di Kerajaan Israel. Dimana raja dan tentara Israel pergi memerangi kerajaan-kerajaan di sekitarnya. Hal yang selalu dinantikan orang Israel pada umumnya adalah munculnya pembawa berita entahkan itu dari utusan dari tentara Israel yang pergi berperang kini datang dan muncul di balik atau di atas gunung-gunung atau bukit-bukit dan memberitakan bahwa tentara mereka menang, raja selamat dan kini mereka sedang dalam arak-arakan pulang dan membawa hasil rampasan. Hal menarik ketika mereka muncul dibalik bukit-bukit atau pegunungan, perhatian tidak lagi diarahkan pada pembawa berita itu tetapi semua mata penduduk Yerusalem akan tertuju pada raja mereka yang datang dalam kemeriahan dan kemegahannya, seperti memimpin pada waktu pergi berperang demikian pula pada waktu kembali memimpin perarakan kemenangan dengan sorak sorai dan gegap gempita muncul di balik bukit-bukit dan menuju ke kota Sion atau Yerusalem. Penduduk Yeruselem menjadi gempar dengan keriuhan dan sorak-sorai karena raja mereka selamat, raja dan tentaranya menang dan membawa hasil rampasan yang luar biasa.

Keindahan ketiga adalah berita yang disampaikan sang pembawa berita itu. Dalam terjemahan NKJV dikelompokkan dua bagian berita ini yaitu pertama, who brings good news who proclaims peace dan who brings good things, who proclaims salvation is who says to Zion "Your God Reigns". Untuk memudahkan memahaminya, menurut saya, dalam bagian ini Yesaya mengurutkan tiga karakteristik kabar berita tersebut yaitu kabar berita damai (proclaims peace), kabar berita baik (proclaims the good things or the good news), dan kabar berita selamat (proclaims salvation). Ketiga karakter berita ini bermuara pada kalimat "Allahmu itu Raja" penyebabnya.

\section{a. Kabar berita damai (proclaims of peace)}


Dalam masa peperangan zaman dulu, berita damai berkenaan dengan dua hal yaitu penaklukkan total suatu kerajaan jadi tidak mungkin adalagi pemberontakan, perlawanan, peperangan kecuali menyerahkan diri pada pihak yang menang, kedua terjadinya kesepakatan di antara dua kelompok atau kerajaan yang sedang berperang. Untuk menghindari korban dan kerugian yang lebih banyak, biasanya dilakukan perdamaian. Tentunya maksud Yesaya di sini, bukanlah diarahkan pada kedua hal itu, karena pada saat itu orang Israel sedang ditindas dan dianiaya oleh bangsa-bangsa Babel. Tidak mungkin akan terjadi perdamaian karena bukan dalam kontek berperang, Israel saat itu sedang ditawan dan sedang diperbudak bukan sedang berhadapan dan saling memperhitungkan kekuatan dan kelemahan, keuntungan dan kerugian. Saat itu orang Israel tak berdaya dan tidak punya kemampuan apa-apa, jadi tidak mungkin ada perdamaian dalam konteks peperangan. Tetapi Yesaya mengarahkan pada hal yang sangat subtansial yaitu Allah yang murka atas ketidaktaatan dan dosa-dosa Israel dan telah mendatangkan hukuman baginya melalui pembuangan, tetapi sekarang Allah telah menyesal dan segera memulihkan keadaan mereka kembali, bahwa Allah sedang memperdamaikan dirinya dengan Israel, Allah telah memulihkan relasi dan komunikasi dengan umat-Nya. Allah mau berdamai dengan orang Israel dan menerimanya kembali menjadi umat dan anak-anak-Nya. Allah mau menjadikan raja bagi mereka,dan mereka menjadi rakyat yang dipimpin-Nya.

b. Kabar berita baik (proclaims the good things or the good news)

Setelah terjadinya perdamaian, akan ada banyak hal yang bisa diperbuat demi kebaikan dua belah pihak. Terutama kepada para pemenang peperangan. Pada zaman lampau ketika Raja dan Bangsa Israel memenangkan peperangan, kerajaan-kerajaan yang dikalahkan berjanji tidak akan mengganggu lagi dan bahkan akan berjanji memberi kontribusi besar bagi kemajuan dan pengembangan kerajaan Israel. Apakah itu berupa dukungan upeti (pajak), suplai makanan, atau pengerahan tenaga kerja (pekerja) untuk membangun kota istana, tembok dan kota Yerusalem. Termasuk juga bagaimana beritaberita baik itu akan dirasakan manfaatnya di masa yang akan datang oleh orang atau rakyat banyak terutama soal keamanan (jauh dari gangguan gerombolan), meningkatnya kesejahteraan dalam hal kesehatan, pertanian, peternakan, kecukupan makanan, dan terbukanya lapangan pekerjaan, pendidikan dan lain sebagainya. Tetapi sebaliknya kerajaan yang menang juga akan memperlakukan kerajaan yang dikalahkan itu sebagaimana mestinya tidak lagi menindas dan menghajarnya tetapi sebaliknya akan menjadi bagian pendukung kemajuan, memberi bantuan pengawasan, pemeliharaan, dan perluasan wilayah kerajaan.

\section{c. Kabar berita selamat (proclaims of salvation)}

Yesaya menekankan bahwa Allah akan selalu bertindak dalam hal-hal praktis dan prinsip hidup manusia, terkhususnya bagi umat-Nya Israel di pembuangan. Allah memang akan menyelamatkan mereka dan membawa mereka kembali ke Zion, ke kota Yerusalem. Ini menjadi penghiburan bagi orang-orang Israel di pembuangan. Tetapi lebih daripada itu, Yesaya mengingatkan dan menegaskan hal prinsip bahwa Allah adalah adalah penyelamat sejati di dunia dan akhirat. Yesaya meyakinkan orang Israel di pembuangan bahwa Allah yang dikenalnya itu adalah Allah yang menebus, Allah yang membebaskan dan memerdekakan, serta Allah yang menyelamatkan. Penebusan dan penyelamatan Allah itu tidak hanya soal mereka ditebus dan diselamatkan dari perbudakan di Mesir, perbudakan di Asyur dan di Babel melainkan berlaku sampai dimensi yang paling mendalam di antara relasi Allah dengan menusia yaitu penebusan dan penyelamatan dari dosa manusia, yang pada saat itu mereka tidak sadari mengapa mereka berada di pembuangan karena mereka berdosa kepada Allah. Yesaya 1:18 "Marilah, baiklah kita berperkara! -- firman TUHAN -- 
Sekalipun dosamu merah seperti kirmizi, akan menjadi putih seperti salju; sekalipun berwarna merah seperti kain kesumba, akan menjadi putih seperti bulu domba."

Dari bagian ini, mengingatkan bahwa sejak awal sejarahnya, Israel sadar bahwa TUHAN sendiri yang memerintah dan memelihara umat-Nya. Dia Raja mereka (Bil.23:21; Kel.15:18). Dalam hal ini Israel berlainan dari bangsa-bangsa tetangga, dimana masyarakatnya tak dapat dipikirkan tanpa seorang raja - entah raja itu dipandang sebagai manusia ilahi, seperti halnya di Mesir, atau sebagau wakil bangsanya dan pengantara antara rakyat dan para dewa, seperti halnya di Asyur - melalui raja berkat ilahi mengalir menjamin ketentaraman masyarakat dan ketertiban alam. Di Israel cukuplah TUHAN adalah Raja, Yesaya II menegaskan bahwa Israel selamat, karena TUHAN sendiri adalah Raja mereka.

Namun demikian, dalam sejarah Israel Tuhan juga berkenan agar umat-Nya juga mempunyai seorang raja untuk memerintah atas mereka dan memimpin mereka dalam perang (1 Sam.8:5, 10); bahkan pasca Saul disingkirkan dari raja (Kis. 13:21-22), dipilihNya Daud dan keturunannya dan diberkati-Nya mereka menjadi raja (1 Sam.7; Mzm.2, 72, 89). Serentak dengan itu TUHAN memilih Yerusalem sebagai tempat, dimana Ia berkenan diam (2 Sam.6, 1 Raj.8; Mzm. 87:122). Raja-raja keturunan Daud dan kota Sion tidak dapat dipisahkan lagi dari sejarah kerajaan Israel; sejak tahun 1000 sampai dengan tahun 587, terutama kehidupan kerajaan Selatan berkisar di situ. Ketika raja-raja keturunan Daud meninggal dan kota-kotanya runtuh, kelihatan seolah-olah Israel dihapus atau telah punah sebagai bangsa. Tetapi kini dikatakan kepada Sion: Allahmu memerintah sebagai Raja. Pilihan Sion sebagai kerajaan tidak dibatalkan, tetapi raja yang tinggal di situ bukan lagi keturunan Daud atau keturunan manusia, melainkanr rajanya sekarang bernama Tuhan. ${ }^{10}$

Menurut kisahnya di Babel, tempat orang Israel dibuang, pada pergantian musim, bila tanah tandus dan hidup manusia serasa terancam, diadakanlah upacara-upacara untuk memperingati perlawanan antara kuasa baik Marduk (Dewa baik Babel) dan kuasa tidak baik dari pengacau Tiamat (Dewa tidak baik Babel) atau konteks Indonesia Jin Baik dan Jin Jahat. Setelah orang-orang atau para pemuja, maju sambil menangis dan mengeluh mencari Marduk, maka dibebaskanlah dia dan dipuji karena kemenangannya dan diantar dalam pawai ke purinya, di mana ia diproglamasikan sebagai "Marduk raja". Permulaan tahun baru pemerintahannya - dan pemerintahan raja yang dilantiknya - dirayakan dengan meriah. Kepada kaum buangan yang bertahun-tahun menyaksikan upacara tersebut diberitahukan bahwa Raja yang sesungguhnya adalah Tuhan Allah di Sion. ${ }^{11}$ Bukan Dewa Marduk atau Dewa Tiamat.

Berbeda dengan yang di Yerusalem, di dalam ibadah di Bait Suci di Yerusalem Tuhan yang dipuji sebagai Raja seantero dunia (Yes.6:1-6; Mzm.24:7-10). Sejumlah mazmur dinyanyikan untuk Raja yang menjadikan alam (Mzm.93:1-3; 95:1-5; 96:6-10), Ia berkuasa atas para allah (Mzm. 95:3; 96:4), Ia pun tinggal di Sion (Mzm. 97:8; 98:7), Raja ini yang akan datang menghakimi dunia dengan keadilan (Mzm. 97:8; 99:9). Pujian inilah yang dinyaringkan Nabi Yesaya kepada kaum buangan di Babel. Dan mengajak mereka untuk melihat dengan mata iman. Kalimat dilihatnya dengan mata kepala sendiri (harfiah: dari mata ke mata, atau seperti dari muka ke muka-Bil.14:14), dimana orang buangan akan melihat Tuhan akan kembali ke Sion, artinya Tuhan akan kembali kepada puluhan ribu orang Israel yang berada di pembuangan, akan menebusnya, akan menyelamatkannya (Zak.8:3), dan akan membawanya ke kota Sion, di Yerusalem.

Dalam ayat 9-10, tidak hanya manusia (orang-orang buangan) yang bersyukur, alampun turut bergembira (Yes. 42:10-11; 43:23), melainkan seluruh bumi penuh sorak- 
sorai atas keselamatan Israel, disitu dinyatakan kemuliaan Tuhan di depan mata sekalian orang (Yes.40:5, 6:3).

5. Conclusio (Kesimpulan) "Allah yang berjalan di depan dan menjadi penutup barisan di belakang"

Pada ayat 11-12, Orang-orang buangan diingatkan akan keluaran dari Mesir (Kel.3:12, 18; 5:1), dan mereka kini mau dipersiapkan untuk menjauh, keluar, dan meninggalkan daerah pembuangan (Yes. 40:1; 59:9,17) menuju ke Sion, kota Yerusalem, kota Daud leluhur mereka, kota dimana Tuhan yang menjadi raja dan memerintah di sana. Mengenai siapa yang akan kembali ke kota Yerusalem, Yesaya dalam pasal 10:21-22 menuliskan bahwa "suatu sisa akan kembali, sisa Yakub akan bertobat di hadapan Allah yang perkasa. Sebab sekalipun bangsamu, hai Israel, seperti pasir di laut banyaknya, namun hanya sisanya akan kembali, Tuhan telah memastikan datangnya kebinasaan dan dari situ akan timbul keadilan yang meluap-luap." Kaum sisa yang akan kembali ini, akan mendiami kota Yerusalem. Di kota itulah, mereka akan melakukan ibadah. Dan para imam mereka akan berjalan sambil mengangkat perkakas rumah Tuhan. Dulu perkakas ini pernah di bawa ke Babel oleh raja-rajanya (2 Rj. 25:13-17; 2 Taw. 36:6), dalam pemerintahan Koresy keputusannya akan mengembalikan apa yang masih ada untuk dipakai kembali dalam ibadah kepada Allah di sorga di Yerusalem (Ez. 1:7-11), hal ini mau mengingatkan Israel dan kita akan tabut Allah lambang kehadiran Tuhan di antara umat-Nya (Bil.10:33-36), tetapi mungkin perkakas yaitu emas dan perak yang dibawa dari Mesir (Kel. 3:22; 12:3536).

Kaum sisa yang yang turut atau ikut kembali ke kota Sion, Yerusalem, dan yang ikut dalam kebaktian, tidak boleh kena kepada yang najis, harus menyucikan diri, mereka harus memisahkan diri dari unsur-unsur agama dan budaya kafir yang memengaruhi mereka secara lahir dan batin selama mereka di pembuangan. Pada keluaran baru menuju kota damai sejahtera-kota Sion, orang-orang tidak terburu-buru lagi karena Allah yang membawa dan menyertai mereka, Allah yang berjalan di depan mereka dna menjadi penutup mereka (Kel.13:21-22, 14:19, Ul. 1:30). Orang Israel di pembuangan diajak pulang untuk berbakti dan bersyukur kepada Raja dan penyelamat mereka di Sion, Yerusalem. Nabi Yesaya mengundang dan mengajak orang Israel menyucikan diri dan mengikuti Allah mereka sebagai raja di Yerusalem. Pemberitaan ini digenapi Allah dalam pemerintahan Koresy, raja Persia dengan merestui kepulangan orang Israel ke tanah Kanaan. Bakker menjelaskan bahwa biarlah Israel mendasarkan kepercayaannya kepada Tuhan, oleh karena Allah akan membebaskan mereka dan memakai Koresy, raja Persia sebagai alat untuk menghancurkan kekuasaan Bebal dan memulangkan Israel ke tanah Kanaan. ${ }^{12}$

Dalam perjalanan kepulangan itu, Allah akan menjadi pemimpin di depan mereka dan juga menjadi penutup dibarisan belakang bangsa Israel. Hal ini mengingatkan bangsa Israel ketika keluar dari tanah perbudakan di Mesir, Allah menjadi tiang Awan di siang hari dan menjadi tiang api di malam hari. Allah yang memimpin di depan dan Allah juga yang memimpin di belakang mereka (Kel. 14:19).

6. Korelasi Berita Yesaya dengan Mikha, Nahum dan Rasul Paulus

Pemberitaan Yesaya direkam baik oleh nabi-nabi dizamannya seperti Mikha dan Nahum dan menjadi buah pengajaran Rasul Paulus dalam surat-suratnya.

\section{a. Nabi Mikha}

Mikha yang sezaman dengan Yesaya bernubuat di masa pemerintahan raja Yotam dan Hizkia, ia memanggil semua bangsa untuk menyaksikan hukuman yang akan didatangkan Allah atas Yerusalem dan Yehuda. Samaria telah tenggelam, Yerusalem juga 
akan ikut tenggelam. Ia memberitahukan hukuman atas dosa Israel. Tetapi jikalau hukuman itu telah dijalani mereka, maka Allah akan mengaruniakan umat-Nya. Orang yang akan memerintah itu akan lahir di Betlehem (Mik. 5:1), maka sisa-sisa Israel akan pulang kembali, lalu datanglah kerajaan damai. Kedatangan Mesias, itu tidak akan hanya bagi Israel saja, tetapi juga bagi segenap bangsa, mereka juga akan datang ke bukit Allah dan dimasukkan ke dalam umat Allah. ${ }^{13}$

\section{b. Nabi Nahum}

Nahum yang disebut orang Elkosy, berasal dari Elkosy di daerah Yehuda di Galilea atau Yudea yang hidup di zaman Manasye raja Yehuda. Ia memberitakan tentang tenggelamnya kota Niniwe yang terjadi tahun 612 sM. Niniwe akan dihancurkan sama seperti kota Mesir dan Kota Asyur lainnya ditahun 613. Diantara tahun ini nabi Nahum memberitakan nubuatnya. Nahum memberitakan tentang keadilan dan kemurahan hati Allah "Tuhan itu baik bagi orang yang menanti-nantikan Dia, menjadi tempat pengungsi (Nah. 1:7). Keadilan itu Nampak juga dari hukuman Allah atas segala musuh Tuhan, Niniwe yang selalu mengancam Yehuda, akan dihancurkan dan ditenggalamkan oleh hukuman Allah, dan Tuhan akan membebaskan umat-Nya. ${ }^{14}$ Nabi Nahum pada abad 7 sM juga menyaksikan bagaimana keindahan berita keadilan, kemurahan dan kedamaian Allah itu, disampaikan kepada umat Israel yang tersisa dan pemberitanya memesona pandangan Nabi Nahum, sehingga ia menuliskan hal itu demikian "lihatlah di ats gunung-gunung berjalan orang yang membawa berita, yang mengabarkan berita damai sejahtera, rayakanlah hari rayamu, hai Yehuda, bayarlah nasarmu! Sebab tidak akan datang lagi orang dursila menyerang engkau ia, telah dilenyapkan sama sekali" (Nah. 1:15). Kalimat "betapa indahnya kelihatan dari puncak bukit-bukit" merujuk ke hal tersebut. Sungguh indah kelihatan langkah (kaki yang sedang berjalan), atau permai kedatangan pemberita kabar berita damai, kabar berita baik, dan kabar berita keselamatan yang akan disampaikan dan dialamatkan kepada kota Yerusalem, kota raja, kota dimana Allah akan menjadi raja dan memerintah sebagai raja di sana.

Yesaya telah mempersiapkan rujukan pasal 52:7 berkenaan dengan lahirnya Raja Damai. Dalam Yesaya 8:23-9:1-6 "Tetapi tidak selamanya akan ada kesuraman untuk negeri yang terimpit itu. Kalau dahulu TUHAN merendahkan tanah Zebulon dan tanah Naftali, maka di kemudian hari Ia akan memuliakan jalan ke laut, daerah seberang sungai Yordan, wilayah bangsa-bangsa lain. Bangsa yang berjalan di dalam kegelapan telah melihat terang yang besar; mereka yang diam di negeri kekelaman, atasnya terang telah bersinar. Engkau telah menimbulkan banyak sorak-sorak, dan sukacita yang besar; mereka telah bersukacita di hadapan-Mu, seperti sukacita di waktu panen, seperti orang bersorak-sorak di waktu membagi-bagi jarahan. Sebab kuk yang menekannya dan gandar yang di atas bahunya serta tongkat si penindas telah Kaupatahkan seperti pada hari kekalahan Midian. Sebab setiap sepatu tentara yang berderap-derap dan setiap jubah yang berlumuran darah akan menjadi umpan api. Sebab seorang anak telah lahir untuk kita, seorang putera telah diberikan untuk kita; lambang pemerintahan ada di atas bahunya, dan namanya disebutkan orang: Penasihat Ajaib, Allah yang Perkasa, Bapa yang Kekal, Raja Damai. Besar kekuasaannya, dan damai sejahtera tidak akan berkesudahan di atas takhta Daud dan di dalam kerajaannya, karena ia mendasarkan dan mengokohkannya dengan keadilan dan kebenaran dari sekarang sampai selama-lamanya. Kecemburuan TUHAN semesta alam akan melakukan hal ini."

Yesaya dalam syair utamanya (Yes.51:9-52:12) mengingatkan bagaimana Tuhan mendirikan kerajaan-Nya di Yerusalem dengan melepaskan umat-Nya yang terbuang di Babel, dan membawanya ke Sion. Jalan keselamatan itu hanya berada di dalam Tuhan

\footnotetext{
${ }^{13}$ Bakker, Sejarah Kerajaan Israel 1, 761
}

14Bakker, Sejarah Kerajaan Israel 1, 761 
sendiri. Dalam kontek Perjanjian Baru, raja Damai itu ada di dalam diri Yesus Kristus sebagai kedatangan kerajaan Allah, sudah dekat (Mrk. 1:15), bahkan diam di antara manusia (Luk.17:21).

\section{c. Rasul Paulus}

Sebagai orang Yahudi dan terdidik soal Taurat dan kisah-kisah penyelamatan Allah dalam Perjanjian Lama terhadap manusia berdosa, dan bagaimana berita keselamatan itu diberitakan dari satu generasi ke generasi lainnya, Paulus sangat memahami teks dan konteks ini. Dalam dua suratnya, Rasul Paulus memberikan porsi penjelasan akan pentingnya berita indah itu diberitakan.

\section{1) Roma 10:9-15}

Paulus menuliskan Surat Roma dalam perjalanannya yang ketiga, kira-kira tahun 58$59 \mathrm{M}$ di Kengkrea (Korintus). ${ }^{15}$ Diberikan inspirasi tentang keindahan berita damai itu bersama dengan pemberitanya. Dalam Roma 10:9-15, Paulus menuliskan "Sebab jika kamu mengaku dengan mulutmu, bahwa Yesus adalah Tuhan, dan percaya dalam hatimu, bahwa Allah telah membangkitkan Dia dari antara orang mati, maka kamu akan diselamatkan. Karena dengan hati orang percaya dan dibenarkan, dan dengan mulut orang mengaku dan diselamatkan. Karena Kitab Suci berkata: "Barangsiapa yang percaya kepada Dia, tidak akan dipermalukan." Sebab tidak ada perbedaan antara orang Yahudi dan orang Yunani. Karena, Allah yang satu itu adalah Tuhan dari semua orang, kaya bagi semua orang yang berseru kepada-Nya. Sebab, barangsiapa yang berseru kepada nama Tuhan, akan diselamatkan. Tetapi bagaimana mereka dapat berseru kepada-Nya, jika mereka tidak percaya kepada Dia? Bagaimana mereka dapat percaya kepada Dia, jika mereka tidak mendengar tentang Dia. Bagaimana mereka mendengar tentang Dia, jika tidak ada yang memberitakan-Nya? Dan bagaimana mereka dapat memberitakan-Nya, jika mereka tidak diutus? Seperti ada tertulis: "Betapa indahnya kedatangan mereka yang membawa kabar baik!"

Rasul Paulus dalam beberapa suratnya seperti dalam Roma 10:14-15, ia menguraikan bagaimana jalur pemberitaan damai sejahtera itu bagi orang Israel sampai orang-orang percaya masa kini, melalui keempat pertanyaan ia melacak seluruh jalan yang dilalui kabar itu, yakni dalam urutan yang terbalik, dari penerimaannya dengan beriman (percaya) lewat didengarnya kabar baik itu (mendengar) dan pemberitaannya (memberitakanNya), serta sampai ke pengutusan para pemberitanya (diutus). Kedua pertanyaan yang pertama menyangkut sudut manusia, kedua yang terakhir menyangkut perbuatan Allah. Maka yang terakhir itulah yang paling penting, sebab perbuatan Allah merupakan pangkal kabar itu. Kalau tidak ada utusan, tiada pula pemberitaan, lalu takkan ada pula orang yang mendengar, dan yang menjadi percaya.

Paulus menjadikan Yesaya 52:7 sebagai bukti keabsahan jabatannya sebagai rasul, walaupun menurut cara pikir moderen kita tidak ada hubungan, tetapi perlu diperhatikan bahwa teologi kaum rabi terhadap Yesaya 52:7 dikaitkan dengan zaman Mesias. Karena itulah Paulus dapat menghubungannya pula dengan karyanya sendiri. Sebab sang Mesias telah datang, yaitu Yesus Kristus. Pemberitaan Paulus berpusat pada Yesus Kristus, Mesias itu, bahkan ditugaskan kepadanya oleh Yesus Kristus sendiri (Kis.9). Jadi dalam Roma 10:14-15 para rasul, termasuk Paulus sendiri, telah diutus Allah untuk membawa kabar tentang keselamatan yang dianugerahkan-Nya. ${ }^{16}$

Secara terknis, Barclay menganalisa dengan tepat bahwa jalan kepada Allah bukan karena usaha dan menuruti peraturan hukum Taurat, melainkan dengan beriman dan kepercayaan. Tetapi sekarang bagaimana jika orang-orang (termasuk Yahudi) tidak pernah mendengar hal itu. Pertanyaan inilah yang ingin dijawab oleh Paulus dalam Roma 10:14-15.

${ }^{15}$ RA Jaffray, Tafsiran Surat Roma (Bandung: Kalam Hidup, 2007), 12

16Th. Van Den End, Tafsiran Alkitab Surat Roma (Jakarta:BPK. Gunung Mulia, 2015), 279-281 
Pertama, "kamu tidak dapat berseru kepada Allah, kecuali engkau percaya kepada-Nya. Engkau tak dapat percaya kepada-Nya, kecuali engkau mendengar tentang Dia, engkau tidak dapat mendengar tentang Dia kecuali ada orang yang memberitakan kabar baik itu kepadamu. Tak mungkin ada yang memberitakan kabar baik itu, kecuali Allah mengutus seseorang untuk melakukannya. Paulus menghadapi keberatan itu dengan mengutip Yesaya 52:7, di sana nabi menyatakan, alangkah indahnya kedatangan mereka yang membawa kabar baik. Berdasarkan ayat itu Paulus menegaskan, "Kamu tidak dapat mengatakan, tidak ada utusan, Yesaya telah menceritakan tentang utusan-utusan itu; dan Yesaya adalah nabi yang hidup pada masa yang lampau".

Kedua, ialah: "tetapi kenyataannya Israel tidak menaati kabar baik itu, meskipun argumentasimu benar. Apa yang akan kamu tentang itu?"jawab paulus : "ketidakpercayaan Israel memang sudah diduga, karena pada waktu yang lalu yesaya telah tergerak untuk mengatakan dalam keputusanya: "TUHAN, siapakah yang percaya kepada pemberintaan kami?"(Yes 53: 1) dan benarlah, Israel telah menolak kabar baik dari ALLAH. Suatu pengunguylan sejarapun telah terjadi.

Ketiga,ialah suatu pernyataan kembali dari yang pertama: "tetapi, bagaimana jikalau aku menegaskan bahwa mereka sebenarya tidak pernah mendapat kesempatan untuk mendengarnya?" kali ini paulus mengutip dari (Mzm. 19:5) "gema mereka terpencar keseluru dunia dan perkataan mereka sampai keujung bumi" Jawabnya: "kamu tidak dapat mendengar; karena kitab suci telah jelas mengatakan berita ALLAH telah terpencar keseluru dunia."

Keempat ialah: "tetapi bagaimana kalau Israel tidak mengerti?" rupanya yang dimaksud ialah: "bagaimana jikalau kabar itu amat sulit untuk ditangkap, sehingga meskipun Israel mendengarnya,mereka tidak menangkap maksudnya?" disinilah persoalan ini benar-benar sulit. Tetapi jawab paulus:"mungkin Israel telah gagal untuk mengertinya; tetapi bangsa-bangsa lain tidak. Merekap dapat menangkap tawaran ini, ketika tawaran itu datang kepada mereka tampa disangka dan dicari." Untuk membuktikan hal ini, Paulus mengutip dua ayat. Yang satu dari (Ul. 32:21) dimana Allah berkata bahwa, karena ketidaktaatan dan pemberontakan Israel, ia akan mengalikan kasinya kepada umat lain,dan mereka akan cemburu kepada bangsa-bangsa itu. Bagian kedua ialah dari (Yes. 65:1) dimana Allah mengatakan, dengan cara yang luar biasa ialah telah ditemukan suatu umat yang sama sekali tidak mencari dia. Akhirnya Paulus menegaskan bahwa sepanjang sejarah, Allah telah mengulurkan tangannya kepada Israel, tetapi Israel tetap tidak taat dan menantangnya.

\section{2) Efesus 6:15}

Berdasarkan informasi Kisah Para Rasul, Paulus tiba di Efesus pertama kali pada pelayanannya yang kedua (dimusim gugur tahun $52 \mathrm{M}$ ) dan melayani di sinagoge untuk sementara waktu dan kembali ke Yerusalem (Kis. 18:18-21). Ia kembali setahun kemudian pada perjalanan misi ketiga dan menetap di Efesus selama dua setengah tahun. Dia meninggalkan Efesus pada musim semi tahun 56 M (Kis. 19:1-20:1). Setahun kemudian ia mengunjungi tua-tua jemaat di Efesus di Miletus dalam perjalanannya ke Yerusalem dari Korintus (Kis. 20:16-18). ${ }^{17}$

Paulus masih dipengaruhi pemikiran bahwa berita damai itu harus disampaikan oleh pemberita-pemberita yang rela, atau sukarela, tanpa pamrih mau memberitakan Injil. Yang menarik bahwa sikap kerelaan ini menjadi bagian terpenting dari sikap seseorang yang menggunakan perlengkapan senjata Allah dalam peperangan rohani. Rasul Paulus menuliskan dalam Efesus 6:15 "kakimu berkasutkan kerelaan untuk memberitakan Injil Damai Sejahtera". O’Brien menterjemahkan berkasutkan/mengenakan kasut mengutip 
pemikiran D.B. Wallace yang mengkategorikan partisipel perizōsamenoi (mengenakan) sebagai partisipel sarana. ${ }^{18}$ Artinya bahwa sang pemberita kabar berita damai, kabar berita baik dan kabar berita keselamatan itu memerlukan sarana kerelaan yang melekat pada dirinya untuk pergi memberitakan Injil keselamatan dalam Kristus.

7. Betapa Indahnya Mereka Yang Datang Membawa Damai Dalam Dunia Pendidikan Bagaimana tema "Betapa Indahnya Mereka Yang Datang Membawa Damai" di dalam Dunia Pendidikan". Dalam bagian ini akan dipaparkan beberapa hal yaitu: Bagaimana pendidikan Kristen?, Bagaimana pendidik atau pengajar Kristen melakukannya, Bagaimana Kurikulumnya? dan bagaimana tata kelola pendidikan secara institusi.

a. Bagaimana Pendidikan Kristen sebenarnya? Termasuk yang berlaku di STT?

Bagaimana pendidikan Kristen yang sebenarnya?, Daniel L. Mars dalam tulisannya "The Place of Religion In Education" yang dikutip Lois E. Lebar, bahwa "Pendidikan semestinya membuat kita bergairah, penuh semangat dan sukacita dalam menjalani hidup ini...19 Lois E. Lebar mengatakan menantang kaum pendidik Kristen dengan pertanyaan apakah ajaran di sekolah-sekolah Alkitab Injili menimbulkan gairah, semangat dan sukacita? Apakah pekabaran Injili kita bergaung dan menggetarkan kehidupan?, Apakah Tuhan Yesus Kristus yang adalah hidup dan satu-satunya sumber kehidupan begitu dekat dan nyata di dalam pengajaran kita sehingga hidup mengalami perubahan setiap waktu. Apakah pendidikan yang dimaksud dianggap sebuah petualang yang hebat bersama sang Maha Guru Agung? Tuhan Yesus.... Apakah pengajaran kita membuat mata para murid kita berbinar-binar matanya terhadap visi dan wawasan baru dengan tekad serius untuk melakukan kehendak Allah dan menggenapi rencana Allah dalam hidupnya?. ${ }^{20}$

b. Bagaimana pendidik dan pengajar termasuk institusi melakukannya?

Bagi Lois E. Lebar penulis buku "Education That is Christian: Proses Belajar Mengajar Kristiani \& Kurikulum yang Alkitabiah" hal ini hanya bisa dilakukan oleh institusi pendidikan dan para pendidik jika mereka percaya, menerima dan mau belajar pada Guru yang datang dari Allah, yaitu Yesus Kristus yang adalah Guru yang ahli, sebab Dia sendiri mengejawantahkan kebenaran itu secara sempurna, Dia memahami secara sempurna murid-murid-Nya, Dia menggunakan metode-metode dengan sempurna untuk mengubah umat, sebab Dialah sendiri "Jalan, Kebenaran dan Hidup" (Yoh. 14:6). ${ }^{21}$

Pendidikan Kristen adalah pendidikan interaksi, pendidikan yang mengalirkan keteladanan dan kehidupan. itu ${ }^{22}$ Itulah sebabnya diperlukan suatu kerjasama antara manusia dengan yang ilahi. Guru manusia bekerja bersama-sama dengan Guru Ilahi. Di sini, sekolah Kristen (termasuk STT) membicarakan betapa pentingnya tempat Roh Allah dalam pendidikan Kristen.

Suatu tulisan mengatakan "berdoalah seolah-olah semuanya bergantung kepada Allah; Bekerjalah seolah-olah semuanya bergantung kepada Anda." Terhadap pernyataan ini, Lois E.Lebar menjelaskan posisi penyelenggaran pendidikan dan pendidik "Seberapa menolongnyakah nasihat ini? Apakah semuanya bergantung kepada Allah?, jika demikian halnya, mengapakan dunia ini belum selamat? Mengapa Yang Mahakuasa tidak menggunakan kuasa-Nya yang tidak terbatas untuk menghancurkan semua musuh-musuhNya dengan satu pukulan? Ia dapat dengan mudah melakukannya. Tetapi Ia telah memilih

\footnotetext{
${ }^{180}$ Brien, Tafsiran Pilihan Momentum: Surat Efesus, 576

${ }^{19}$ Lois E. Lebar, Education That is Christian: Proses Belajar Mengajar Kristiani \& Kurikulum yang Alkitabiah (Malang: Gandum Mas, 2006), 19

${ }^{20}$ Lebar, Education That is Christian: Proses Belajar Mengajar Kristiani \& Kurikulum yang Alkitabiah, 21

${ }^{21}$ Lebar, Lebar, Education That is Christian: Proses Belajar Mengajar Kristiani \& Kurikulum yang Alkitabiah, 75 
untuk membatasi diri-Nya dengan apa yang akan kita lakukan, dan untuk bekerja melalui kita, bahkan bekerja melalui kita.

Kita tidak dapat berdoa seolah-olah semuanya bergantung kepada Allah, karena ini bukanlah kehendak Allah. Dan tentu saja semunya ini tidak tergantung kepada kita. Kesalahan ini bahkan jauh lebij buruk dari yang sebelumnya. Karena, Allah dapat bekerja dalam anugerah-Nya yang penuh kuasa tanpa kita, walaupun ia jarang memilih untuk melakukannya. Apabila kita bekerja seolah-olah semuanya bergantung kepada kita, kita akan meneruskan usaha sia-sia, menghabiskan waktu dan tenaga kita di dalam daging yang tidak menghasilkan apa-apa. Ada banyak pengajaran Kristen yang hanya memberi dampak yang kecil buat kekekalan karena kita tidak mengetahui apakah bagian yang harus dikerjakan oleh Guru Ilahi dan apakah bagian yang dikerjakn guru manusiawi. ${ }^{23}$

Richard J. Edelin mengutip pemikiran Cornelius Van Til, mengatakan "Guru Kristen harus mengenal dirinya sendiri, mengenal bidang studinya, dan mengenal anak-anak didiknya. Ia mempunyai keyakinan penuh tentang hasil utama dari pekerjaannya. Ia bekerja keras untuk mendapatkan hasil yang kekal". ${ }^{24}$ Di sini integritas intelektual dan konsistensi dipertaruhkan bersama dengan kebutuhan untuk mengerti berbagai perspektif yang berbeda terhadap perubahan sosial dan pendidikan. Kekristenan dan pendidik Kristen terpanggil melayani masyarakat sesuai dengan imannya. ${ }^{25}$

c. Bagaimana inti kurikulum pendidikan Kristen?

Bagaimana kurikulum pendidikan Kristen?, kurikulum tidak hanya berbicara sejumlah mata kuliah yang disediakan oleh institusi untuk diajarkan oleh para pendidik atau pengajar (dosen) dalam kuruan waktu tertentu dan yang akan diambil seorang mahasiswa untuk lulus, di wisuda, diberi ijazah dan gelar akademik, bukan pula hanya berupa perubahan-perubahan dan pengalaman-pengalaman baru dari akibat mendapatkan pengetahuan, sikap dan keterampilan yang baru. Melainkan bagaimana kurikulum pendidikan Kristen itu mempengaruhi totalitas kehidupan para peserta didik. Nicolas P. Wolterstorff menuliskan Kurikulum Pendidikan Kristen adalah untuk kehidupan Kristen. Bukan melatih orang-orang menjadi pakar theology, bukan keberlansungan oragnisasi gereja-gereja, bukan untuk melestarikan kelompok-kelompok Kristen, bukan untuk mengalahkan komunis, bukan untuk penyeseuai hidup, bukan untuk memupuk kehidupan akal budi, bukan untuk menghasilkan kelompok terpelajar dan berbudaya. Pendidikan Kristen adalah untuk kehidupan Kristen. ${ }^{26}$

d. Bagaimana tata kelola pendidikan Kristen?

R. Eko Indrajit dan R. Djokopranoto dalam buku "Manajemen Perguruan Tinggi Modern" menjelaskan tantangan globalisasi saat ini tidak hanya menyangkut dan berdampak pada bidang ekonomi, tetapi pada hampir seluruh elemen kehidupan manusia, maka globalisasi pun berdampak pada pendidikan tinggi dan perguruan tinggi, cepat atau pun lambat... tampaknya tidak lama lagi kekuatan dan gejalanya tidak dapat dibendung lagi. ${ }^{27}$

Pergerakan bebas pengetahuan, persaingan mutu proses dan lulusan,SDM,sarana dan prasarana, persaingan merekrut mahasiswa baru, dan lain sebagainya akan menjadi panorama penyelenggaraan pendidikan tinggi di Indonesia, khususnya di lingkungan STT.

${ }^{23}$ Lebar, Education That is Christian: Proses Belajar Mengajar Kristiani \& Kurikulum yang Alkitabiah,

${ }^{24}$ Richard J.Edelin, Hakikat Pendidikan Kristen (Jakarta: BPK. Gunung Mulia, 2015), 469

${ }^{25}$ Robert W. Pazmino, Fondasi Pendidikan Kristen (Jakarta: BPK. Gunung Mulia, 2012), 260.

${ }^{26}$ Nicholas Wolterstorff, Mendidikan Untuk Kehidupan (Surabaya: Momentum, 2007), 23

${ }^{27}$ R. Eko Indrajit dan R. Djokopranoto, Manajemen Perguruan Tinggi Modern (Yogyakarta: Yayasan Andi, 2006), 94 
Sebenarnya melalui Undang-undang Sistem Pendidikan Nasional (UU SISDIKNAS Nomor 20 Tahun 2003), Undang-Undang Nomor 12 Tahun 2012 tentang Pendidikan Tinggi, Undang-Undang Nomor 14 Tahun 2005 tentang Guru dan Dosen, Permenristek Dikti Nomor 44 Tahun 2015 tentang Standar Nasional Perguruan Tinggi (SNPT), dan Permenristek Dikti Nomor 32 Tahun 2016 tentang Akreditasi Program Studi (APS) dan Akreditasi Institusi Perguruan Tinggi (AIPT) dan undang-undang, peraturan pemerintah, peraturan menteri lainnya, kita sudah bisa mengetahui bagaimana tata kelola institusi pendidikan yang kita diselenggarakannya.

\section{Kesimpulan}

Mari memaknai tema ini dalam konteks tata kelola perguruan tinggi yang dipercayakan kepada kita bahwa betapa bahagianya penyelanggara pendidikan (khususnya STT) beserta dengan civitas dan stakeholders-nya karena menyelenggarakan perguruan tinggi teologi sesuai dengan firman Tuhan, sesuai dengan undang-undang, sesuai dengan peraturan pemerintah, sesuai dengan peraturan menteri, sesuai dengan Badan Akreditasi Nasional (BAN-PT), dan bahwa betapa bahagianya para dosen dan mahasiswa berbagai program studi dari berbagai jenjang pendidikan (Sarjana, Magister, dan Doktor), dan para lulusan serta para orangtua karena institusi dan prodinya memenuhi syarat akreditasi. Dan betapa bahagianya mereka di mata masyarakat, karena mereka dibanggakan dan hormati dari institusi dan prodi yang terakreditasi, ijazah dan gelarnya dipakai (atau memenuhi syarat untuk mendaftar pekerjaan dan melamar CPNS, dan lulusan memiliki pengetahuan, sikap dan keterampilan yang diperlukan dalam pelayanan dan pekerjaan.

\section{Referensi}

Bakker, FL., Sejarah Kerajaan Allah. Jakarta: BPK. Gunung Mulia, 1990.

Djokopranoto R dan R. Eko Indrajit, Manajemen Perguruan Tinggi Modern. Yogyakarta: Yayasan Andi, 2006.

Edelin, Richard J., Hakikat Pendidikan Kristen. Jakarta: BPK. Gunung Mulia, 2015.

End, Th. Van Den, Tafsiran Alkitab Surat Roma. Jakarta: BPK. Gunung Mulia, 2015.

Jaffray, RA, Tafsiran Surat Roma. Bandung: Kalam Hidup, 2007.

Kissane, E.J. "The Book of Isaiah I " dalam J.D. Dauglas (penyunting), Ensiklopedi Alkitab Masa Kini Jilid II M-Z. Jakarta: YKBK/OFM, 2007.

Lebar Lois E., Education That is Christian: Proses Belajar Mengajar Kristiani \& Kurikulum yang Alkitabiah. Malang: Gandum Mas, 2006.

Marie-Claire Barth, Tafsiran Alkitab: Kitab Yesaya Pasal 40-55 (Jakarta: BPK. Gunung Mulia, 1996), 297

O’Brien Peter T., Tafsiran Pilihan Momentum: Surat Efesus. Surabaya: Momentum, 2013.

Pazmino Robert W., Fondasi Pendidikan Kristen. Jakarta: BPK. Gunung Mulia, 2012.

Wolterstorff, Nicholas, Mendidikan Untuk Kehidupan. Surabaya: Momentum, 2007. 
Jurnal Luxnos Vol. 4, No. 2, Edisi Agustus - Desember 2018

Http://psbrahmana.blogspot.com/2012/12/khotbah-yesaya-527-10-senin-24desember.html (diakses 20 Juli 2018). 